Journal of Applied Pharmaceutical Science Vol. 2 (10), pp. 045-049, October, 2012

Available online at http://www.japsonline.com

DOI: $10.7324 / \mathrm{JAPS} .2012 .21009$

ISSN 2231-3354 (cc) BY-NC-SA

\title{
Phytochemical Analysis and Antiviral Potential of Aqueous Leaf Extract of Psidiumguajava Against Newcastle Disease Virus in ovo
}

\author{
1,4* Chollom S.C., ${ }^{1}$ Agada G.O.A., ${ }^{1}$ Bot D.Y., ${ }^{4}$ Okolo M.O, ${ }^{2}$ Dantong D.D., ${ }^{1}$ Choji T. P., ${ }^{3}$ Echeonwu B. C., ${ }^{5}$ Bigwan E.I., \\ ${ }^{1}$ Lokason $\mathrm{S}$ and ${ }^{4}$ Banwat E. \\ ${ }^{1}$ National Veterinary Research Institute, Vom, Plateau State, Nigeria. \\ ${ }^{2}$ Faculty of Veterinary Medicine, University of Abuja, Abuja, Nigeria. \\ ${ }^{3}$ Federal College of Veterinary and Medical Laboratory Technology, Vom, Plateau State, Nigeria. \\ ${ }^{4}$ Department of Medical Microbiology, University of Jos, Plateau State, Nigeria. \\ ${ }^{5}$ Department of Medical Laboratory Science University of Jos, Plateau State, Nigeria.
}

\section{ARTICLE INFO}

Article history:

Received on: 10/09/2012

Revised on: 09/10/2012

Accepted on: 15/10/2012

Available online: $28 / 10 / 2012$

Key words:

Phytochemical Screening,

Newcastle Disease Virus,

Psidium guajava, In ovo

\begin{abstract}
Leaf extract of Psidium guajava were subjected to phytochemical screening and in ovo antiviral assay against Newcastle Disease Virus (NDV). Phytochemical analysis revealed the presence of pharmacologically active and nutritionally relevant compounds. Nine-day-old embryonated chicken eggs were divided into ten groups of fives and received various treatments. Groups 1-6 received $100 \mathrm{EID}_{50} / 0.1 \mathrm{ml}$ NDV pre-treated with $P$. guajava leaf extracts at final concentrations of $250,200,100,50,25$ and $10 \mathrm{mg} / \mathrm{ml}$ in that order. Controls were included. Embryo survival was observed daily. Allantoic fluid from treated eggs and serum from hatched chicks were collected for spot hemagglutination (HA) and hemagglutination inhibition (HI) tests to detect NDV in the eggs and antibodies against NDV in the hatched chicks respectively. Results showed that embryo survival was higher with higher extract concentrations.. Just as increase in extract concentration was directly proportional to virus death and inversely proportional to production of antibody against NDV in hatched chicks. The current findings have clearly demonstrated that $P$. guajava leaf extract has nutritional value as well as great antiviral potential against NDV in ovo. In vivo trials are needed to validate the use of the tree in controlling Newcastle disease in chickens.
\end{abstract}

\section{INTRODUCTION}

The apple guava (Psidium guajava) or common guava has nearly a global presence. It is an evergreen shrub or small tree native to Mexico, the Caribbean, and Central and South America (Psidium guajava, 1995). It is a common shade tree or shrub in door-yard gardens in the tropics. The tree is easily identified by its distinctive thin, smooth, copper-colored bark that flakes off, showing a greenish layer beneath. Lozoya et al. (2002) reported that the phytochemical analyses of guava leaf, revealed the presence of more than 20 isolated compounds with quercetin as the main active substance. Spasmolytic and antidiarrheal effects are reported to be associated with its quercetin-derived, flavonoids

\footnotetext{
* Corresponding Author

Department of Medical Microbiology,

University of Jos, Plateau State, Nigeria
}

and glycosides, which support use of this ancient leaf remedy in treating gastrointestinal disorders (Joseph and Priya, 2011).plants remained the primary 2011). The plant is used in many different shampoo products for its scent. It is also becoming a popular Bonsai Species and is currently quite popular in India and Eastern Asia (Mark, 2011). Local preparations made from the leaves and/or bark of Psidium guajava are reported to be useful in treatments of diarrhea, dysentery, sore throats, vomiting, stomach upsets and vertigo. They have also been found to be effective in regulating menstrual periods throughout the tropical Amazon and India (Holetz et al., 2002). Also, tender leaves of the plants are also reported to be chewed for bleeding gums and bad breath, and it is said to prevent hangovers when they are chewed before alcohol consumption. According to the report, Indians throughout the Amazon gargle a leaf decoction for mouth sores, bleeding gums, or 
use it as a douche for vaginal discharge and to tighten and tone vaginal walls after childbirth (Holetz et al., 2002; Nwogu et al., 2007) Very recently, some plants were screened for antiviral potential against NDV. Bakari et al., (2012) examined crude extracts from Commiphora swynnertonii against the virus, Suleiman et al., (2011) also demonstrated that root bark of baobab (Adansonia digitata Linn) can inhibit NDV in ovo. Newcastle disease has remained unabated the world over in spite of the various intervention programs including vaccination. It is a highly infectious disease of domestic poultry and wild birds. It is caused by a virus and is widely regarded as one of the most important avian diseases. Although most avian species are susceptible to infection with the virus that causes Newcastle disease, chickens are the most susceptible to clinical disease (Young et al., 2002). Newcastle disease was first recognized in Indonesia and England in 1926 (Doyle, 1927) and Newcastle disease viruses are now found worldwide (Aldous and Alexander, 2001). NDV is classified by Office international des Epizooties (OIE) as a list 'A' disease: it spreads rapidly, extends beyond national borders, and has serious socioeconomic consequences and major trade implications. It is of major importance in both commercial and village chicken flocks where it may cause outbreaks with up to $100 \%$ mortality (Young et al., 2002).

\section{MATERIALS AND METHODS}

\section{Collection and Identification of the Plant Material}

Fresh leaves of $P$. guajava were randomly collected from different areas in Tapo, Barkin- Ladi Local Government Area of Plateau State, Nigeria. The plant was first identified at the field using standard keys and descriptions (Dalziel, 1956; Keay, 1989). It's botanical identity was further confirmed and authenticated at the Federal College of Forestry in Jos.

\section{Preparation of Plant Extract}

The leaves of $P$. guajava were sorted to eliminate any dead matter and other unwanted particles after which they were air-dried for 2 weeks and pulverized before the commencement of the extraction. The extraction was carried out as described by Njar et al. (1993) and Raji (1995). The pulverized leaves weighing 245g was exhaustively extracted with distilled water by means of cold extraction and extract evaporated in vacuo. The leaf extract was then concentrated in vacuo using a rotary evaporator at $40^{\circ} \mathrm{C}$. The solvent remaining in the extract was finally removed by placing the extract in porcelain dishes in temperature-controlled oven to give a residue weighing $9.55 \mathrm{~g}$. The resulting extract was reconstituted in $9.55 \mathrm{ml}$ of sterile distilled water to give a final concentration of $1000 \mathrm{mg} / \mathrm{ml}$.

\section{Phytochemical Screening}

Phytochemical screening was carried out as earlier described by Sofowora(1993) as documented earlier by Dalen et al., (2009).

\section{ANTIVIRAL ASSAY}

Source of Virus and 9-Day Old Embryonated Chicken Eggs

A velogenic strain of NDV was obtained from Viral Research Department while embryonated chickens eggs were obtained from Poultry Division both of National Veterinary Research Institute, Vom, Nigeria.

\section{Determination of EID $_{50}$ of the virus}

The $\mathrm{EID}_{50}$ of the virus was determined as recorded by Young et al., (2002). From this, $100 \mathrm{EID}_{50} / 0.1 \mathrm{ml}$ of the virus stock was made for the experiment.

\section{Preparation of Inoculum (Virus/Extract mixture)}

A $1: 2 \mathrm{v} / \mathrm{v}$ dilution of the $100 \mathrm{EID}_{50} / 0.1 \mathrm{ml}$ of virus with predetermined extract concentrations was made to put extract final concentration in the virus/extract mixture at $250 \mathrm{mg} / \mathrm{ml}, 200 \mathrm{mg} / \mathrm{ml}$, $100 \mathrm{mg} / \mathrm{ml}, 50 \mathrm{mg} / \mathrm{ml}, 25 \mathrm{mg} / \mathrm{ml}$ and $10 \mathrm{mg} / \mathrm{ml}$. The virus/extract mixtures were kept at $4^{\circ} \mathrm{C}$ for $1 \mathrm{hr}$ to react.

\section{Inoculation of Eggs}

Nine-day-old embryonated chicken eggs were divided into ten groups of fives. The embryonated chicken eggs were labeled according to the extract concentrations used. A set of plastic egg trays were thoroughly cleaned with Virkon ${ }^{\circledR}$, the eggs were swabbed with $70 \%$ alcohol in cotton wool and transferred into the cleaned trays. The swabbed eggs were placed in the microsafety cabinet where they were punched and immediately inoculated with the extract/virus mixture via the allantoic route. Groups 1-6 were inoculated with $0.2 \mathrm{ml}$ of virus/extract mixtures at final concentrations of $250 \mathrm{mg} / \mathrm{ml}, 200 \mathrm{mg} / \mathrm{ml}, 100 \mathrm{mg} / \mathrm{ml}$, $50 \mathrm{mg} / \mathrm{ml}, 25 \mathrm{mg} / \mathrm{ml}$ and $10 \mathrm{mg} / \mathrm{ml}$ in that order. Group 7 was inoculated with $0.2 \mathrm{ml} 100 \mathrm{EID}_{50} / 0.1 \mathrm{ml}$ standard NDV (virus control), group 8 was inoculated with $0.2 \mathrm{ml}$ extract suspension at $250 \mathrm{mg} / \mathrm{ml}$ concentration (extract control). Group 9 was inoculated with $0.2 \mathrm{ml}$ phosphate buffered saline (diluent control) while group 10 had eggs that were not inoculated with anything (uninoculated control). The eggs were sealed with molten wax and incubated at $37^{\circ} \mathrm{C}$. Embryo survival was observed daily while a few eggs from selected groups were left to hatch. Allantoic fluid from treated eggs were collected for spot test and haemagglutination test to detect NDV in the eggs while serum from hatched chicks were collected for hemagglutination inhibition (HI) tests to detect antibodies against NDV in the hatched chicks.

\section{Spot haemagglutination test}

Dead embryos that had been chilled were brought out of the refrigerator and kept at room temperature for about $30 \mathrm{~min}$. The eggs were swabbed and placed in the biosafety cabinet. The shell of each egg was opened to reveal the air space and a pipette was used to dispense a drop of $1 \%$ washed chicken red blood cells on a white tile. A wire loop was thoroughly flamed and used to pick a drop of the allantoic fluid which was mixed with the drop of blood. 
The tile was gently rocked and observed for visible agglutination, indicating viral activity (Thayer and Beard, 1998; Murakawa et al., 2003). This was done for every egg and the observations were recorded.

\section{Haemagglutination Inhibition Test}

This was conducted on serum of hatched chicks to ascertain the titre of antibody against NDV. The protocol of Young et al., (2002) was adopted.

\section{RESULTS}

Phytochemical analysis of the extract revealed the presence of Pharmacologically active substances (Table I). Elemental analysis on the other hand showed the presence of important mineral salts (Table II). P. guajava leaf extract at $250 \mathrm{mg} / \mathrm{ml}$ and $200 \mathrm{mg} / \mathrm{ml}$ concentrations completely inhibited virus growth in embryonated eggs as revealed by the survival of embryos of the inoculated eggs. Also, Spot HA test of allantoic fluids of eggs inoculated with extracts at these concentrations did not show any agglutination. Furthermore, chicks that hatched out from some eggs at these concentrations were apparently healthy and had no antibodies against the virus. The negative results of spot heamagglutination test in these concentrations buttress this point (Table III). Embryos of inoculated eggs with extract at concentration of $10 \mathrm{mg}, 25 \mathrm{mg} 50$ and $100 \mathrm{mg}$ partially inhibited virus growth as various degrees of mortality in the embryos of the eggs were observed. The control groups were also perfect in their outcomes. The extract and diluent controls were safe for the experiment in the eggs as revealed by embryo survival while the virus control was potent enough as it killed all the embryos within $48 \mathrm{hrs}$ post inoculation. Uninoculated controls on the other hand had live embryos throughout the duration of the experiment.
The outcome of HI test on hatched chicks showed increasing NDV antibody titres with decreasing extract concentrations (Table III).

Table. 1: Result of Phytochemical screening of $P$. guajava leaf extract.

\begin{tabular}{ll}
\hline Compound & Present \\
\hline Alkaloids & ++ \\
Tannins & + \\
Flavonoids & ++ \\
Saponin & ++ \\
Glycosides & + \\
Reducing compounds & + \\
\hline KEY & \\
$++=$ Highly present, + = Present &
\end{tabular}

Table. 2: Result of Elemental studies of Psidium guajava leaf extract.

\begin{tabular}{ll}
\hline Elements & Concentration $(\mathbf{p p m})$ \\
\hline Calcium & $10.00 \pm 0.011$ \\
Zinc & $0.70 \pm 0.021$ \\
Iron & $0.45 \pm 0.011$ \\
Manganese & $45.10 \pm 0.022$ \\
Sodium & $130.30 \pm 0.010$ \\
Potassium & $200.40 \pm 0.013$ \\
Phosphorus & $2.20 \pm 0.012$ \\
\hline
\end{tabular}

\section{DISCUSSION}

P. guajava tree has a long history of medicinal uses that are still employed today (Nwinyi et al., 2008). The reason behind this is not far - fetched as revealed by phytochemical analyses of the leaf in this study. The presence of pharmacologically useful substances such as alkaloids, tannins, flavonoids, saponins among others in the leaves confirm the diverse claims and application of parts of the plant in local treatment of ailments. Previously, it has been documented that guava contains broad spectrum of phytochemicals including polysaccharides, vitamins, essential oils (Smith and Siwatibau,

Table. 3: Results of Antiviral Activity of Psidium guajava leaf extract against NDV.

\begin{tabular}{|c|c|c|c|c|c|c|c|c|c|}
\hline \multirow{2}{*}{$\operatorname{Extract}(\mathbf{m g} / \mathrm{ml})$} & \multicolumn{5}{|c|}{ Mortality (pi) } & \multicolumn{4}{|c|}{ HA Test } \\
\hline & No Eggs & $24 \mathrm{hr}$ & $48 \mathrm{hr}$ & $72 \mathrm{hr}$ & $96 \mathrm{hr}$ & +ve & -ve & $\%$ Mortality Due to Virus & Mean Ab Titre \\
\hline 250 & 5 & $0 / 5$ & $0 / 5$ & $0 / 5$ & $0 / 5$ & 0 & 5 & 0 & $\leq 1 / 2$ \\
\hline 200 & 5 & $0 / 5$ & $0 / 5$ & $0 / 5$ & $0 / 5$ & 0 & 5 & 0 & $\leq 1 / 2$ \\
\hline 100 & 5 & $0 / 5$ & $0 / 5$ & $1 / 5$ & $1 / 4$ & 2 & 3 & 40 & $1 / 8$ \\
\hline 50 & 5 & $0 / 5$ & $1 / 5$ & $2 / 4$ & $1 / 2$ & 4 & 1 & 80 & $1 / 32$ \\
\hline 25 & 5 & $0 / 5$ & $2 / 5$ & $3 / 3$ & - & 5 & 0 & 100 & $1 / 128$ \\
\hline 10 & 5 & $0 / 5$ & $5 / 5$ & - & - & 5 & 0 & 100 & $1 / 512$ \\
\hline $\mathrm{Vc}$ & 5 & $0 / 5$ & $5 / 5$ & - & - & 5 & 0 & 100 & ND \\
\hline $\mathrm{Ec}$ & 5 & $0 / 5$ & $0 / 5$ & $0 / 5$ & $0 / 5$ & 0 & 5 & 0 & ND \\
\hline Dc & 5 & $0 / 5$ & $0 / 5$ & $0 / 5$ & $0 / 5$ & 0 & 5 & 0 & ND \\
\hline $\mathrm{Uc}$ & 5 & $0 / 5$ & $0 / 5$ & $0 / 5$ & $0 / 5$ & 0 & 5 & 0 & ND \\
\hline
\end{tabular}

KEY

Vc: Virus Control

Ec: Extract Control

Dc: Diluent Control

Uc: Uninoculated Control

ND: Not Done

Pi: Post Inoculation

Ab: Antibody 
1975, Macleod and Troconis, 1975), minerals, enzymes, proteins (Deo and Shastri, 2003), sesquiterpenoid alcohols and triterpenoid acids (Smith et al, 1975; Wilson111 and Shaw, 1978; Begum et al., 2002), alkaloids, glycosides, steroids, flavanoids, tannins, saponins (Cho et al., 2003; Narayana et al., 2001; Geidam et al., 2007).

Also, the presence of key elements in $P$. guajava leaves as revealed by elemental analysis is no doubt responsible for the high nutritional value of the fruit. Hassimotto et al. (2005) reported that guavas are often included among superfruits, being rich in dietary fiber, vitamins A and $\mathrm{C}$, folic acid, and the dietary minerals, potassium, copper and manganese. Having a generally broad, low-calorie profile of essential nutrients, a single common guava ( $P$. guajava) fruit contains about four times the amount of vitamin $\mathrm{C}$ as an orange (Joseph and Priya, 2011).

Results of antiviral assay of P.guajava from this study confirm that the leaf had antiviral potential against NDV. This was revealed by the complete inhibition of virus growth in ovo at $200 \mathrm{mg} / \mathrm{ml}$ and $250 \mathrm{mg} / \mathrm{ml}$. At these concentrations, all the inoculated eggs had live embryos just as sera of hatched chicks had no antibodies against NDV implying that the plat extract at these concentrations inhibited the growth of the virus.

Also, HI test results showed increasing NDV antibody titre with decreasing extract concentration. This implies that the antiviral potential of the plant was concentration based. It is therefore safe to conclude that the higher the extract concentration, the more the antiviral activity.

This is not strange considering the phytochemical composition of the leaf and previous citations of the antiviral potential of the leaf extract against some pathogenic microorganisms.

In several studies, guava showed significant antibacterial activity against common diarrhea-causing bacteria such as Staphylococcus, Shigella, Salmonella, Bacillus, E. coli, Clostridium and Pseudomonas. Lozoya et al. (2002) reported that a double-blind clinical study of the effects of a Phytodrug (QG- 5) developed from guava leaf showed a decrease in duration of abdominal pain, which is attributed to antispasmodic effect of quercetin present in leaf extract (Joseph and Priya, 2011).

The microbicidal activity of Psidium guajava is attributable to guajaverine and to psydiolic acid (Berdy et al., 1981). The leaves of guava have been found to contain large amounts of tannin, triterpernoids (crategolics, guaijavolic, oleanolics and ursolic acids) and essential oils containings sitosterol, s-bisabolene, scariophyllene, aromadendrene, ssalinene, guaijaverine, nerolidiol and sel-11-en-4_-ol (Morton,1981).

Also, investigation on the antiviral potential of the plant has previously been documented: Direkbusarakom et al.
(1997) tested Psidium guajava extract for antiviral activity against the fish pathogenic viruses, infectious, haematopoietic necrosis virus (IHNV) infectious pancreatic necrosis virus (IPNV) and Oncorhynchus masou virus (OMV) using plaque reduction in CHSE-214 cell lines. Antiviral tests against the shrimp pathogenic virus, yellow-head virus (YHV), they tested the efficacy of guava extract using MIC of the extract against 24 strains of pathogenic bacteria including Vibrio harveyi $(9$ strains), V. splendidus (7 strains), V. parahaemolyticus (2 strains) and 1 strain of each $V$. mimicus, $V$. vulnificus, $V$. fluvialis, $V$. cholerae, $V$. alginolitycus and Aeromonas hydrophila. They found that the extract of guava demonstrated antiviral activity against IHNV, OMV and YHV but was not effective for IPNV (Joseph and Priya, 2011).

These findings are scientific and relevant judging from the performance of the control groups. The virus control was potent enough to cause embryo death within $48 \mathrm{hrs}$ post inoculation just as extract, diluents and uninoculated controls did not interfere with embryo survival signifying the acceptability of the outcome of the tests groups.

\section{REFERENCES}

Aldous EW and Alexander DJ Deteaction and differentiation of Newcastle

Disease Virus (avian paramyxovirus type 1). Avian Pathol. $2001 ; 30: 117-128$

AOAC Official methods of Analysis. Association of analytical Chemists. Washington, D.C, USA, 1975; pp 450

Bakari GG., Max RA., Mdegela RH., Phiri EC., Mtambo MM. Antiviral activity of crudeextracts from Commiphora swynnertonii against Newcastle disease virus in ovo. Trop Anim Health Prod. 2012.

Begum S., Hassan SI., Siddiqui BS. Two new triterpenoids from the fresh leaves of Psidium guajava. Planta Med. 2002; 68: 1149-1152.

Berdy J., Aszalos A., Bostian M., Mcnitt K.L. CRC Handbook of antibiotic compounds. Boca Raton, CRC Press, 1981; Part 1.

Cho EJ., Yokozanawa T Y., Rhyu DY., Kim S.C., Shibahara N., Park JC. Study on the inhibitory effects of Korean medicinal plants and their main compounds on the 1-diphenyl-2-piccrylhydrazyl radical. Phytomed. 2003; 10:544-551

Dalen MB., Pam JS., Izang A and Ekele R. Synergy between Moringa oleifera seed powder and alum in the purification of domestic water. Sci. World J. 2009;4:4

Dalziel JM. Useful plants of West tropical Africa. Crown Agents for Oversea Government and Administration, London, 1956; 23pp.

Direkbusarakom S., Herunsalee A., Yoshimizu, M. et al. Efficacy of guava (Psidium guajava) extracts against some fish and shrimp pathogenic agents. In: FLEGEL, T. W. \& MAC RAE, I. H., ed. Diseases in Asian Aquaculture III: Fish Health Section, Manila Asian Fisheries Society, 1997; 363.

Deo A and Satri NV Purification and characterization of polygalacturonase inhibitory proteins from Psidium guajava Linn. (Guava) fruit, Plant science. 2003; 164:147-56

Doyle TM. A hitherto unrecorded disease of fowls due to a filter-passing virus. J. of Comp. Pathol. 1927. 
Geidam YA., Ambali AG., Onyeyili PA. Phytochemical screening and antibacterial properties of organic solvent fractions of Psidium guajava aqueous leaf extracts. Int'l. Journ. of Pharmacol. 2007;3 (1):68-73.

Hassimotto NM and Genovese MI. Antioxidant activity of dietary fruits, vegetables, and commercial frozen fruit pulps. Journ. Agric. Food Chem. 2005; 53(8): 2928-2935.

Holetz FB. et al. Screening of some plants used in the Brazilian folk medicine for the treatment of infectious diseases. Mem. Inst. Oswaldo Cruz 2002; 97(7):1027-1031

Joseph B. and Priya RM. Review of nutritional, medicinal and pharmacological properties of guava (Psidium guajava Linn) Int'l J. of Pharma Bio Science. 2011; Vol2/ Issue 1

Lozoya X., Reyes-Morales H., Chavez-Soto MA., MartinezGarcia Mdel C., Soto-Gonzalez Y., Doubova SV. Intestinal antispasmodic effect of a phytodrug of Psidium guajava folia in the treatment of acute diarrheic disease. J Ethnopharmacol. 2002; 83(12):19-24.

Macleod AJ and Troconis NG. Volatile flavor components of guava, Phytochem. 1975;21:1339-42.

Morton JF. Atlas of medicinal plants of Middle America. Springfield, Charles C.

Murakawa Y., Sakaguchi K., Soejima K., Eriguchi S., Takase K., Sueyoshi M., Nagatomo H.,Ito T., Otuski K Heamagglutinating activity of the lentogenic Newcastle disease virus strain MET95. Avian Pathol. 2003; 32(1): 39-45.

Narayana KR., Reddy MS., Chaluvadi MR., Krishna DR Bioflavanoids: classification, pharmacology, biochemical effects and therapeutic potential, Indian Journal of Pharmacol. 2001; 33:2-16.
Njar VCO., Alao TO., Okogun JI., Holland HL. 2 methoxy cathin-6-one: A new alkaloid from the stem wood of Quassia amara. Planta Med. (1993); 59: 259-261.

Nwinyi OC., Chinedu NS., Ajani OO. Evaluation of antibacterial activity of Psidium guajava and Gongronema Latifolium, J. Med. Plants Res. 2008; 2(8): 189-192,

Nwogu LA., Alisi CS., Ibegbulem CO., Igwe CU. Phytochemical and Antimicrobial Activity of ethanolic extract of Londolphia owariensis leaf. Afr. J. Biotechnol. 2007; 6(7) :890-893

Smith RM and Siwatibau S. Sesquiterpene hydrocarbons of Fijian guavas, Phytochem. 1975; 14:2013-2015

Sofowora A. Medicinal Plants and Traditional Medicine in Africa, Spectrum Books Ltd Ibadan.1993.

Sulaiman LK., Oladele OA., Shittu IA., Emikpe., BO., Oladokun AT and Meseko CA In-ovo evaluation of the antiviral activity of methanolic root-bark extract of the African Baobab (Adansonia digitata Lin).Afr. J. of Biotech. 2011;10(20) 4256-4258

Thayer SG and Beard CW Serologic procedures. In: Swayne E, Glisson JR, (1998).

Jackwood MW, Pearson JE, Reed WM (eds). A laboratory manual for the isolation and identification of avian pathogens. American Association of Avian Pathologists. Kennett Square, PA. USA pp. 255-266

Wilson111 C.W., Shaw P.E., Terpene hydrocarbons from Psidium guajava. Phytochemistry. 17:1435-6, (1978)

Young M, Alders R, Grimes S, Spradbrow P, Dias P, da Silva A and Lobo Q (2002).Controlling Newcastle disease in village chickens: A laboratory manual ACIAR monograph No 87 142pp

\section{How to cite this article:}

Chollom S.C., Agada G.O.A., Bot D.Y., Okolo M.O, Dantong D.D., Choji T. P., Echeonwu B. C., Bigwan E.I., Lokason S and Banwat E. Phytochemical Analysis and Antiviral Potential of Aqueous Leaf Extract of Psidium guajava Against Newcastle Disease Virus in ovo. J App Pharm Sci. 2012; 2 (10): 045-049. 